\title{
Cambodian Labour in Chinese-0wned Enterprises in Sihanoukville. An Insight into the Living and Working Conditions of Cambodian Labourers in the Con- struction, Casino and Manufacturing Sectors
}

\author{
Joe BUCKLEY' ${ }^{1}$, Christian ECKERLEIN² \\ SOAS, University of Fribourg
}

\begin{abstract}
China is by far Cambodia's largest foreign investor. These investments are said to have had a huge impact on Cambodia's economic, political, cultural, and physical landscape. Sihanoukville, Cambodia's largest coastal city, has seen particularly massive inflows of Chinese investment, especially in the casino, construction and manufacturing sectors. Based on semi-structured interviews, this article investigates the impact of Chinese investments on working conditions of Cambodian workers. We find that conditions are generally bad and wages are low. We argue, however, that this is the case regardless of the nationality of the firm and that there is little difference between Chinese and non-Chinese enterprises with regard to working conditions and labour rights for Cambodian workers.
\end{abstract}

Keywords: Cambodia, labour, trade unions, China, development

\section{Introduction ${ }^{3}$}

The ILO believes that China is committed to creating and promoting decent work, and has developed a Decent Work Country Programme 2016-2020 with the Chinese government (ILO, 2017). In 2018, the ILO signed a South-South Cooperation Agreement with China to promote decent work in Laos, Cambodia, and Myanmar in the context of the Belt and Road Initiative (BRI) (ILO, 2018). Another cooperation agreement between the ILO and China's state-led

\footnotetext{
${ }^{1}$ Joe Buckley holds a PhD in International Development from SOAS, University of London (joe_buckley@soas.ac.uk).

${ }^{2}$ Christian Eckerlein is a sociologist and social worker. He completed his MA in Sociology at the University of Fribourg (christian.eckerlein@fhnw.ch).

${ }^{3}$ This is a shorter version of a report prepared for the Solidarity Center's Cambodia Country Office in Phnom Penh.
} 
union federation, the All China Federation of Trade Unions, was signed in 2019, to help the federation promote decent work in the Asia Pacific (ILO, 2019).

Not all researchers share the ILO's belief. China's role as an investor around the world is heavily debated and has attracted huge amounts of attention in recent years, with many assumptions and accusations levelled at it. Researchers and analysts see it variously as an opportunity, a threat, neo-colonial and neo-imperialist, anticolonial and anti-imperialist, driven by Chinese state interests and strategies, or driven purely by the search for profit. Studies are often hazy about whether they are referring to Chinese state capital, Chinese private capital, or a mixture of both. The impact of Chinese investment on labour rights is largely unknown. Some reports claim that labour rights have worsened due to Chinese capital (Human Rights Watch 2011; Baah and Jauch 2009), while other researchers claim that those reports are largely based on assumptions and unreliable evidence (Lee 2017; Oya and Wanda 2019; Schaefer and Oya 2019).

In Cambodia, the same confusion reigns. Chinese investments are said to have had a huge impact on Cambodia's economic, political, cultural, and physical landscape (Ellis-Petersen 2018; Po and Heng 2019; Vireak 2019). One city that has received special attention and has seen particularly massive inflows of Chinese investment, is Sihanoukville, Cambodia's largest coastal city. The town, which was once popular with western backpackers, has reshaped into a casino hub (Ng and Phang 2018), and countless construction sites shape the cityscape. It is widely considered a "New Macau" (AFP 2019a) and has - within less than two years - become the place with the highest concentration of casinos within the country.

This development has been concurrent with the construction of a new Phnom Penh-Sihanoukville expressway, which Beijing calls a key part of its Belt and Road Initiative (BRI); the expressway is being built by a Chinese State Owned Enterprise (SOE) and financed by Chinese state-backed loans (Ang 2019). Many journalists argue that the impact of Chinese investment in Sihanoukville is negative, documenting how local business owners and self-employed workers, such as tuk tuk drivers, are being driven out of business (Ellis-Petersen 2018; Ng and Phang 2018; Vireak 2019). Those who own land are seen as beneficiaries, as Chinese investment has been driving up rental rates (Prasso 2018; Po and Heng 2019).

Little, though, is known about the impact Chinese investment in Sihanoukville is having on working conditions and labour rights. This article investigates this. It is largely based on semistructured interviews conducted with 75 workers and trade unionists during two research trips to Sihanoukville in June and July 2019. We focus on Cambodian workers in Chinese-owned enterprises in three major sectors: construction, casinos, and manufacturing. We provide a snapshot of the situation at one point in time. Our research questions focus on working conditions, labour rights and trade union / labour activism in these sectors as well as possible differences concerning these issues in Chinese-owned enterprises compared to non-Chinese owned enterprises. We deal exclusively with Cambodian wage employment in Chinese-owned enterprises, rather than Chinese workers.

Although Chinese investment is taking place in various places all around the world, we see Sihanoukville as a particularly interesting case to investigate. The massive, allegedly uncoordinated and ungoverned influx of foreign investment within a very short period of time in one specific place reshaped not only the city's landscape but has severe social and economic impacts 
on its citizens, especially if they are workers. It is these impacts which we are especially interested in and which guided our research.

We find that conditions are generally bad; wages are low and working conditions are poor. Trade unions are almost non-existent, although there have been some inspiring examples of self-organised worker militancy. We argue, however, that this is the case regardless of the nationality of the firm; there is little difference between Chinese and non-Chinese enterprises with regard to labour rights and conditions for Cambodian workers.

\section{Chinese Investment in Cambodia and Sihanoukville}

Cambodia's annual economic growth has averaged around 7\% over the last two decades (World Bank, 2019). Chinese investments have been crucial in bolstering this development. China is by far Cambodia's largest foreign direct investor and accounted for three quarters of Foreign Direct Investment (FDI) in 2018 (World Bank, 2019). From 2013-2017, annual Chinese investments were around 1 billion USD (Kimsay 2018). In 2016, Chinese investment equalled nearly $30 \%$ of total investments in Cambodia (which was 3.6 billion USD), surpassing investment based on Cambodian capital (27.5\%) (Council for Development of Cambodia, 2017).

Davis (2018) argues that one reason why China's share of FDI is rising is due to Cambodia's "drift toward dictatorship" and weakening of labour laws. This has resulted in Western nations' "threatening sanctions", but led to non-Western governments and companies seeing Cambodia as an attractive investment destination. One such sanction has been the recent partial withdrawal of Cambodia's trade preferences with the EU under the Everything But Arms scheme (European Commission 2020).

According to Chheang (2017), Chinese investment in Cambodia is geostrategic rather than purely economic and motivated by China's efforts to exert greater influence in the region and secure access to abundant natural resources. Thus, investments only benefit the economic and political elite. Kubny and Voss (2010) find that, although there have not been any negative effects, the positive effects of Chinese FDI on Cambodia's manufacturing sector have been very limited, mainly due to limited interaction with local firms. Sengor and Sophal (2017: 44) also point to the lack of forward and backward linkages. Nevertheless, they argue that Chinese FDI has had a considerably positive impact on Cambodia's economy asserting that, up to 2013, Chinese FDI created over 600,000 jobs, mainly in trade and the textile and garment industry (Sengor and Sophal 2017: 28).

In Sihanoukville, investments are concentrated in casinos, infrastructure, real estate and resorts, as well as the Sihanoukville Special Economic Zone (SSEZ), one of Southeast Asia's largest Special Economic Zones (SEZs) (Chheang 2017). Investments in Sihanoukville have risen significantly in the past few years: From 2016 until March 2018, 1.3 billion USD was invested in the city, of which more than $80 \%$ originated from China (Prasso 2018; Ellis-Petersen 2018). As a result, it has been reported that Sihanoukville's annual GDP growth is around 1\% higher than economic growth in the rest of Cambodia (Prasso 2018). Workers on Chinese construction sites can earn three times as much as they do on local projects (Ellis-Petersen 2018), although their Chinese colleagues earn much higher (Keeton-Olsen and Yuan, 2019; Po and Heng, 2019). Chinese investment is also reported to have increased job opportunities. For example, the SSEZ has 
created more than 21,000 jobs and this number is expected to rise to 80,000 by 2022 (Faulder and Kawase 2018). Despite these positive impacts, many problems are ascribed to Chinese investment in the city. One of the most critical impacts is the rapid rise in real estate prices, which has led to a multiplication of rent prices (Ellis-Petersen 2018). Together with the increased cost of living, this has pressured local tenants and underprivileged groups of people to leave the area (Millar 2018). The rising costs have also pushed local businesses and self-employed workers such as street vendors away from Sihanoukville, as they make less income and cannot afford to continue to pay their rent (Po and Heng, 2019; Ellis-Petersen, 2018; Fifield, 2018). Furthermore, issues of land-grabbing have been associated with Chinese investment in Sihanoukville (Reaksmey 2018).

\section{The Construction, Casino and Manufacturing Sectors in Sihanoukville}

\section{Construction}

The construction sector is said to have become one of Cambodia's main economic pillars and has overtaken agriculture and tourism as drivers of growth (Southern 2017). There is no comprehensive data on the number of ongoing construction projects in Sihanoukville. According to Sihanoukville's governor Kouch Chamroeun, 819 construction projects have been greenlighted since 2007 (Kunmakara 2019). Little is known about the number of foreign and Cambodian workers in construction in Cambodia in general, let alone Sihanoukville specifically (Keeton-Olsen and Yuan 2019). The boom has attracted many skilled and unskilled Cambodians to work on Sihanoukville's construction sites in order to find a way out of poverty, as construction wages may provide higher incomes than jobs in agriculture or in garment factories (Faulder and Kawase 2018; Muyhong and Keeton-Olsen 2019).

The rapid increase in construction in Sihanoukville has brought with it a number of concerns, most notably substandard labour conditions and negative environmental impacts. Vireak (2019) notes that the city's infrastructure cannot deal with the waste created from construction, resulting in a lack of waste management, sewage systems and water supply. Muyhong and Keeton-Olsen (2019) find that China's unsafe work practices are "replicated on Cambodia's construction sites"; buildings are constructed on unsafe foundations (e.g. sea sand) and workers sleep on-site. Major attention to safety issues on construction sites was generated after a building collapse on June 22, 2019, which led to the death of 28 workers and injured another 26 (AFP 2019b). The collapse was during the night; workers were not working at the time but living on the site; a common practice on construction sites in Sihanoukville. In the aftermath of the collapse, the government announced extensive compensation to the families of the deceased workers and tighter controls over construction projects (Sovuthy 2019; Narin 2019). The government also banned workers from living on-site. This was, however, still practiced a month later (Muyhong and Keeton-Olsen 2019).

Cambodian and Chinese labourers often work alongside each other. Not only are Cambodian workers believed to earn much less than their Chinese counterparts, but they are also said to have no access to mid-management level jobs, which are mainly held by Chinese nationals (Vireak 2019). One of the reasons for this may be the perception of Chinese workers as more 
capable than Cambodian workers. Keeton-Olsen and Yuan (2019) cite a general manager on a Chinese construction site saying that he prefers Chinese workers, as they work longer days and complete projects on time. While recruitment of Chinese workers takes place through subcontractors or agencies and introductions from family and friends, the recruitment of Cambodian workers differs depending on skill; skilled workers usually work in teams and leaders talk to onsite engineers or managers to exchange contacts, while unskilled workers simply walk up to the site and seek employment (Keeton-Olsen and Yuan 2019).

There is very limited trade union representation in the construction sector (Muyhang and Keeton-Olsen 2019), although there have been cases of wildcat strike activity involving Chinese and Cambodian workers taking action together. In March 2019, Cambodian and Chinese labourers building Jiang Kang Casino Hotel struck to demand that their employer provide a living wage and pay wage arrears (Dara 2019a). Beyond Sihanoukville, there has been a reported strike of 100 Cambodian workers and their Chinese site manager over unpaid wages at One Park in the former Boeung Kak Lake area in Phnom Penh, which has been under Chinese Management (Keeton-Olsen and Yuan 2019).

Unreliable wage payments and unpaid wages are a major concern for the Building and Woodworkers Trade Union Confederation (BWTUC), one of Cambodia's largest construction sector unions. It is difficult to hold subcontractors to account when these issues occur, as companies often fail to register with the Cambodian government (Keeton-Olsen and Yuan, 2019). The lack of registration also makes it impossible for unions to identify foreign construction companies (Muyhong and Keeton-Olsen 2019).

\section{Casinos}

The vast majority of Sihanoukville casinos are owned by private Chinese companies (Kotoski and Sokhorng 2017). At the end of 2018, there were 138 licensed casinos in Cambodia; 88 of which are in Preah Sihanouk province (Spiess 2019). In addition to officially registered casinos, dozens of illegal, unlicensed casinos were in operation, often openly and "seemingly without fear of legal action" (ibid.).

In terms of labour, workers in Chinese-owned casinos are often spoken of as some of the winners of the inflows of Chinese capital into Sihanoukville (Ellis-Petersen 2018; Fifield 2018; $\mathrm{Ng}$ and Phang 2018). ${ }^{4}$ Many people have migrated to work in the sector, including those who previously worked at other casinos in the country ( $\mathrm{Ng}$ and Phang 2018). Wages and benefits are seen as high and employers often provide accommodation (ibid). There is seemingly no union presence in Chinese-run casinos in Sihanoukville, although there is evidence of labour conflicts in the sector, which have also led to strike action. Disputes have been over a casino's refusal to provide adequate accommodation, clean drinking water and unpaid bonuses (Post News, 2019) as well as irregular wage payments and the granting of paid holidays (Sen, 2019), among other things.

\footnotetext{
${ }^{4}$ The other winners are considered to be those who own land and can rent it to Chinese nationals and businesses at high prices. The losers are small business owners and own account workers such as tuk tuk drivers (EllisPetersen, 2018; Ng and Phan, 2018; Fifield, 2018).
} 


\section{Industrial production}

In March 2020, Cambodia's Ministry of Economy and Finance announced plans to transform all of Preah Sihanouk province, of which Sihanoukville is the capital, into a multi-purpose special economic zone. The goal is to make it Cambodia's primary industrial hub. The Chinese city of Shenzen is serving as a role model (Chan 2020). Currently, however, almost all industrial and SEZ activity occurs in SSEZ (Blau 2017: 36). It is a joint venture between a Chinese conglomerate and a Cambodian company and receives official support from both governments (Thame 2017: 20). Some researchers clearly consider SSEZ to be part of China's Belt and Road Initiative (Franceschini 2018: 87; Thame 2017:20) or the the "Maritime Silk Road" (Blau 2017:89; Thame 2017:20), while others see it as ambiguous, as it is a joint venture between private Cambodian and Chinese companies (Ang 2019).

A June 2019 newspaper report said that the zone had 161 factories and more than 20,000 workers (Khmer Times 2019). The zone also had plans for significant expansion (Blau 2017: 39). The majority of factories are Chinese (Fifield 2018) and engage in garment manufacturing. However, goods such as steel piping, bicycles, wire hangers, sofa covers, plywood and household products are also produced. Almost all production is for export via Sihanoukville port (ibid). According to Blau (2017: 40), most workers in SSEZ are young rural-urban migrants from Cambodia's southern districts. Many workers have land in their home provinces and send remittances back to their families. SSEZ has on-site housing, although many workers live outside the zone, close enough to walk to work (ibid: 41).

Blau argues that employers "have colluded to prevent competition for labour, by mutually agreeing to pay at minimum rates" (ibid). Consequently, workers struggle to cover their minimum living costs, and many are heavily indebted. In order to survive, workers reduce food spending and remittances, work as much overtime as possible, or have a second job (ibid: 42). A further issue is that workers are hired on repeated, rolling fixed-duration contracts (FDCs) of 3-6 months (Franceschini, 2018: 88) instead of permanent contracts.

While labour laws officially apply in SEZs, including freedom of association rights, tacit agreements may have been made to keep zones union free (Thame 2017: 25). Union officials report the presence of gangsters at housing sites within the zone, who facilitate union busting, keep tabs on worker organising, and ensure discipline (ibid: 41). SSEZ prides itself for getting support from elite units of the Cambodian military and the Cambodian government to ensure security and stability in the zone (ibid: 27). Also, factory owners dismiss workers who have "taken union activity or shown resistance to management [...] and circulate a photo and details of the person preventing them from getting any other work within the SSEZ" (Blau 2017: 43).

\section{Research Aims and Method}

Despite the insights of existing literature, research gaps around the impact of Chinese investment in Sihanoukville remain. First, while there has been interesting and in-depth research into working conditions and (the lack of) trade union and worker activity in SSEZ, similar research has not been conducted on manufacturing outside of SSEZ, the construction sector, or the casino sector. The first aim of this research is to fill this information gap. Second, while unions in 
Sihanoukville may be weak, journalists have reported on wildcat, self-organised strikes undertaken by workers without a union, which in some cases have been successful. We therefore aim to find more information about what labour conflict and trade union activity exists among workers in Chinese-owned enterprises in Sihanoukville. Third, little is known about whether there is anything specifically Chinese about conditions and activism in these sectors. That is, is there is any difference between Chinese capital and any other capital? Many of the labour issues identified are common across Cambodia, regardless of who owns the capital or the nationality of the employer. However, the literature suggests some potential differences between Chinese capital and other capital. For example, Chinese-owned construction projects employing both Chinese and Cambodian workers or Chinese-owned casinos in Sihanoukville potentially paying higher salaries than others. Our third aim is thus to find out if there is any difference between Chinese enterprises and non-Chinese enterprises with regard to labour rights and working conditions.

Research was conducted across two three-day field trips to Sihanoukville in June and July 2019. The research team included the authors of this report, three Solidarity Center staff members, an external translator as well as an external research assistant. We conducted qualitative, semi-structured interviews with workers and unionists in the construction, casino and manufacturing sectors. In total we spoke to 75 participants - 68 workers and 7 unionists - across 11 group interviews and 9 individual interviews. The interviewees also included one union activist from a casino outside of Sihanoukville, union activists and full-time union staffers in the construction sector as well as a full time representative of the Cambodian Labour Confederation (CLC) in Sihanoukville. During two group interviews with construction workers, the workers' manager was present, which clearly changed the dynamic of the interview, as workers were less able to speak freely. The qualitative methods have allowed us to explore causal connections but also mean that we are unable to give any confident, quantitative figures. Wage levels, for example, cannot be taken as absolute figures; that would require large scale wage surveys. Our methods do allow us, though, to provide an interesting snapshot of one point in time.

\section{Empirical Findings}

In what follows, we present the results of our interviews for the sectors under investigation. Note that this is a composition of main findings. A more detailed insight into our empirical findings can be found in the original report. Although foreign investment, be it Chinese or not, may have an impact on labour conditions in general, these vary depending on the sector. For this reason, the findings are presented separately for each sector. They are structured in the order of our research interests: Working conditions, workers resistance and trade union activity and specifics of working for Chinese companies.

\section{Construction}

The majority of respondents were domestic migrants who moved to Sihanoukville especially for work in construction. Some move together with their family and colleagues from one site to another, often working under the same employer. Many live and sleep on-site. Most workers 
have an 8-hour workday with an additional two-hour lunchbreak and work 7 days a week. This does not depend on whether the site is Chinese-owned or not. Forced overtime depends on the workplace and occurs in Chinese as well as in non-Chinese companies. Cambodian workers overall seem to have more freedom to take a day off than their Chinese colleagues, who are reported to often face longer working hours. None of the construction workers had a written contract. Safety issues are prevalent and include a lack of protective equipment such as helmets or shoes. Lack of toilets and clean water is an additional major issue for workers who have to stay on-site. We found no difference between Chinese and non-Chinese sites with regard to these issues.

The general perception is that wages on Chinese construction sites are higher. However, we encountered workers whose wages were as low as on Cambodian construction sites. Wages reported on Cambodian sites ranged from USD 17.50 per day for a team supervisor to 7.50 per day for a female construction worker. On Chinese sites, the highest wage reported was USD 17 per day for a scaffolder and the lowest was USD 10 per day for a tile worker.

As mentioned above, there is no union presence at any construction site in Sihanoukville, although BWTUC is beginning to try and organise. The main challenges to organising include the language barrier between Chinese and Cambodian workers, the fact that Chinese workers are often in more senior positions - and are therefore more likely to be on the managers' side as well as the short-term nature of construction work. It is however important to note that this is the case for construction work worldwide and not specific to Sihanoukville. Also, the type of workplace arrangement can impose difficulties on organising: While some employees work directly for a contractor, others work for a supervisor who organises his own staff (a "gang boss"). The latter workplace arrangement is not attached to a company and therefore not covered by law, which makes it very difficult to organise workers.

There appear to be two major differences between Chinese and non-Chinese construction sites. First, a number of workers on Chinese construction sites reported verbal and/or physical harassment by their employer or their Chinese co-workers. Second, our interviews suggest that irregular and late wage payment seems to be an issue more prevalent on Chinese-owned sites. We urge caution, however, as union representatives suggested that these issues are due to the employer's non-registration as a formal business rather than to the company's nationality. Further research would be needed to bring more clarity.

\section{Casinos}

Our respondents had various positions, such as dealer, dealer inspector, service staff or general manager. Many leave rural homelands and agricultural lives to work in casinos, while some move from casinos in other parts of the country to work in Sihanoukville. Chinese casinos are so dominant in Sihanoukville that they control the nature of wages and conditions. Thus, little comparison can be made to non-Chinese owned casinos. A standard workweek lasts 6 days and workers get 4 days off per month. Casinos are generally open 24 hours, so shift work is required. The standard shift lasts 12 hours. These hours seem to be longer than elsewhere in Cambodia and are to a large extent due to long and frequent breaks. Some workers are frustrated about the length of shifts and many consider it difficult to find jobs in Sihanoukville casinos with 8hour shifts. Wages are generally higher than in other casinos in the country, which is one of the 
main pull factors for workers to move to Sihanoukville. Interview participants reported wages from 430-500 USD per month for a dealer, and 200-300 USD per month for service staff, although during training this can be as low as 150 USD. On top of wages, the casinos provide their staff with free food, accommodation, and transport to and from work. It is these benefits that allows workers to get above the bare minimum needed to survive and to save money to send home to family. Some workers choose not to live in company-provided accommodation because of issues with, for example, the electricity and water supply, which makes it impossible for them to save. One worker we spoke to was not allowed to stay at the company accommodation as she has a child. Her salary of 150 USD per month is equal to her room rent, which is why she takes loans from colleagues to survive and does extra work such as laundry and ironing. Consequently, she is only able to sleep 3-4 hours a night.

No interview participants we spoke to had written contracts, which is common across the country. The only casino in Cambodia that does provide written contracts and other benefits such as contributions to the National Social Security Fund is Nagaworld in Phnom Penh. This casino is the exception as it has a strong union, which in 2013 successfully organised a campaign to win these benefits.

There is no union presence in casinos in Sihanoukville, but there have been instances of wildcat militancy, in which a number of interview participants were involved. One dealer inspector had a can of drink thrown at him by a customer, which caused a head injury. The worker informed his manager and asked for compensation, but only received 100 USD for medical bills. He was very angry about this and resigned. His colleagues launched a 3-day wildcat strike, demanding the management to find a satisfactory resolution for him. In the end, the strike failed. We also talked to workers involved in a strike at a Chinese-owned casino on 13 July 2019, which was reported in the Khmer Times. Workers were protesting against docked wages, irregular wage payments, and for more days off. The strike was successful and led to an agreement being signed between a worker representative, a company representative, and a Labour Department representative (Sen 2019). Interview participants involved in the strike, who work for the service section of the casino, confirmed the report. All staff got the benefits of the strike settlement, including a pay rise and holiday pay. None of the workers had ever discussed joining a union, and some said they did not know what a union was.

\section{Industrial production}

Wages and working conditions in the manufacturing sector in Sihanoukville are poor and seem to match what is known about the manufacturing sector across Cambodia as a whole. Whether working inside or outside SSEZ, most respondents had similar working hours. They work for 6 days and have a 48-hour working week. Many workers frequently work overtime and have little choice not to do so. Interview participants working at different Chinese-owned factories inside SSEZ reported that they cannot refuse overtime when demand is high and can be sacked if they do. Employers sometimes lock the factory doors to force workers to continue to work overtime. Most interview participants - whether in garment or other factories - receive the garment sector minimum wage of 182 USD per month ${ }^{6}$. Through overtime, some could increase their wage to

\footnotetext{
${ }^{6}$ The garment sector is the only sector in Cambodia with a statutory minimum wage.
} 
around 300-400 USD per month. Interview participants had a number of issues with wages. These included irregular and incomplete wage payments, as well as wage deductions when taking sick leave.

A number of workers who work for different Chinese-owned factories in SSEZ but live in the same area, reported issues with their accommodation. They live in privately rented accommodation near the zone, but their current housing will be knocked down once a new block of buildings is constructed. The cost of the new rooms (90 USD / month) and the 6-month deposit, which they need to pay in advance, are beyond their financial means. Workers at a Chineseowned sofa factory in SSEZ told us that they were offered free accommodation inside the factory but prefer to live outside, nearer to the market where it is easier to buy food or because they have family members they want to live with. A room in a village near SSEZ costs around 50-60 USD per month. Workers live with up to 10 other people to save costs.

Unlike in other sectors, labour contracts are more common in the garment sector, which was also reflected in our interviews, although not all workers had written contracts. Some workers who work inside SSEZ did not have written contracts while other participants, working at factories both inside and outside SSEZ, do have written contracts, although these are exclusively FDCs.

None of the interview participants who work at SSEZ have a union in their factory. Evidence of employers colluding with each other inside SSEZ to keep out unions (Blau 2017; Thame 2017) was confirmed to us by a full-time union official. However, there is very little union presence in Sihanoukville's manufacturing industry in general, whether inside or outside SSEZ; the Coalition of Cambodian Apparel Workers Democratic Union (CCADWU), the largest independent union federation in Cambodia's garment industry, only has a presence in 5 factories.

Concerning specifics of Chinese employers, some interview participants reported that their Chinese managers are strict and blame the workers for things that are not their fault, such as not working when there are not enough orders or goods to produce. Most participants, however, said that their Chinese bosses were okay, or that Chinese managers vary in their attitudes and management style. Overall, our interviews suggest that working conditions neither depend on the location (inside or outside SSEZ) nor on the nationality of the ownership of the factory.

\section{Conclusion and Outlook}

Our investigations suggest that working conditions in Chinese-owned enterprises in Sihanoukville are generally bad. Hours are long and especially in the construction sector, health and safety is poor. Proper safety equipment is often not provided, accidents are common, and hygiene and sanitation in workers' facilities is substandard. With the exception of the manufacturing sector, few workers have written contracts. Construction workers often work seven days a week, whereas in manufacturing and casinos, a 6-day workweek is common. Especially in the construction and manufacturing sectors, overtime is very common and frequently enforced. In construction, wages are paid on a daily basis and range from 10-17.50 USD / day. Women's wages are significantly lower. Manufacturing sector workers generally receive the minimum wage for the garment sector - 182 USD per month - even if they work in factories which produce goods other than garments. Workers can earn more through overtime and sometimes 
receive extra payments for transport, food, and regular attendance. Some of the best wages in the city are paid in the casino sector: Dealers can earn 430-500 USD per month, while those in the service sector earn 200 USD-300 USD. Nevertheless, as accommodation prices are so high in the city, it is the extra benefits of free accommodation and food which allow workers to survive and save. Having said that, we urge caution to the interpretation of these numbers, as they are not based on quantitative wage surveys, but information provided during qualitative interviews.

In terms of trade union activity and labour conflict, there is little trade union presence in Sihanoukville. It is very weak in the manufacturing sector and totally absent in the construction and casino sectors. Nevertheless, there are multiple cases of militancy by workers in all sectors. This report has noted a number of strikes by casino workers over issues such as violence by casino customers, wages, and holidays. A half-day stoppage by manufacturing workers in a suit factory outside SSEZ was a big factor in forcing the company to recognise the union. Construction workers have launched strike action and blocked roads in order to demand late and unpaid wages. This has sometimes involved Chinese and Cambodian workers striking together, despite the language barrier which construction sector unions consider an obstacle to organising.

What we have found is, then, clearly not decent work as it is envisaged by the ILO and others. However, this has little to do with whether or not the employer is Chinese. Our research suggests that, in general, there is no difference between Chinese and non-Chinese enterprises with regard to labour rights and conditions for Cambodian workers. Issues such as long working hours, low wages, substandard safety measures and shortcomings regarding health and occupational safety are often common to enterprises across Cambodia, whether Chinese-owned or not. Thus, we suggest that the nationality of the firm seems to have little impact. In the casino and construction sectors, wages may be higher in Chinese-owned enterprises, but further research would be needed to establish this with confidence. There is also some evidence that workers on Chinese construction sites face more frequent abuse from their employers and more frequent issues of late wage payments, although again further research would be required to establish whether this is actually the case. Casinos in Sihanoukville, which are mainly Chineseowned, do seem to pay higher wages than casinos elsewhere in the country. It is however unclear whether Chinese ownership is a causal factor leading to these higher wages.

This report has important implications for organising. As labour rights and conditions in Chinese-owned enterprises are no better or worse than those in other enterprises, organising should not be focused on enterprise ownership. Rather, problems with labour rights and conditions are widespread across Sihanoukville. In terms of organising, it would make sense to find strategic organising targets across the city, such as ports and other major transport and logistical hubs. Second, unions and other Civil Society Organisations (CSOs) should demand that local authorities properly monitor, regulate and inspect enterprises in Sihanoukville, both Chinese and non-Chinese. The case of Sihanoukville shows that the inflow of huge amounts of capital into a single area in a short time period and with little regulation leads to many issues. Unions and CSOs need, therefore, to use their leverage to start making demands on local authorities for proper oversight and regulation.

Although unionisation is weak across the city and the province, there have been some inspiring wildcat strikes organised by non-unionised workers in all three sectors, some of which 
were successful in achieving their demands. These examples show that despite little union presence, there is significant potential for worker solidarity and self-organisation. This could provide a fruitful basis for unionising, and unionisation campaigns should build and support such grassroots militancy.

Finally, there are number of important issues which this report has not looked at, but which further research by other organisations could hopefully provide some insights into. These include: land rights; environmental issues; the impact of Chinese investment on small business owners and self-employed workers such as tuk tuk drivers; conditions for Chinese workers in Sihanoukville; and macro-political economy questions about whether employment in the city is sustainable or a bubble, the extent to which it is driven by crime and money laundering, how it relates to China's BRI, and the interactions between Chinese state capital and Chinese private capital.

It is important to note that since the time of our research, the situation in Sihanoukville has drastically changed. Most notably, the government has issued a ban on online and arcade gambling in Cambodia on August 18, 2019 (Hutt 2019). With an estimated 90\% of the gaming revenue in Sihanoukville stemming from online gambling (Turton 2020), the ban hit the city and its workers hard. The construction boom came to a halt, many Casinos have stopped operations and property prices, which have drastically risen due to the construction and casino boom, have now declined by nearly $80 \%$ (Turton 2020). Consequently, there has been a massive exodus of Cambodian and Chinese workers, many of which were left unpaid (Haffner 2020).

\section{Acknowledgements}

The authors would like to thank everyone at the Solidarity Center field office in Phnom Penh, Cambodia, who was involved in this research, for providing their expertise, guidance and assistance, and especially William Conklin for his generous support. They also wish to express their gratitude to all union members, activists and workers for participating in the interviews, expressing their opinion and giving highly valuable insights into their everyday life and their working conditions. Finally, the authors would like to thank Dr. Sebastian Schief as well as the anonymous reviewers and the editors of socialpolicy.ch for helpful comments and feedback.

\section{Declaration of Conflicting Interests}

The authors declare no potential conflicts of interest with respect to the research, authorship, and publication of this article.

\section{Funding}

This research was funded by the Solidarity Center Cambodia Country Program. 


\section{References}

Agence France-Presse (AFP) (2019a). In Cambodia's 'New Macau', Chinese cash in. Bangkok Post, 25 June 2019. https://www.bangkokpost.com/world/1618658/in-cambodias-new-macau-chinese-cash-in (last accessed 7 April 2020).

Agence France-Presse (AFP) (2019b). Cambodia building collapse: seven people, including five Chinese nationals, charged over tragedy that killed 28 people in Sihanoukville. South China Morning Post, 25 June 2019. https://www.scmp.com/news/asia/southeast-asia/article/3015927/four-chinese-charged-over-cambodian-building-collapse (last accessed $3 \mathrm{Au}$ gust 2019).

Ang, Yuen Yuen (2019). Demystifying Belt and Road: The Struggle to Define China's "Project of the Century"'. Foreign Affairs, 22 May 2019. https://www.foreignaffairs.com/articles/china/2019-05-22/demystifying-belt-and-road (last accessed 11 June 2019).

Baah, Antony Yaw and Jauch, Herbert (eds.) (2009). Chinese Investments in Africa: A Labour Perspective. Windhoek, Namibia: African Labour Research Network.

Blau, Gavan (2017). Cambodian SEZ Index. Unpublished internal report. Solidarity Center, Phnom Penh, Cambodia.

Buckley, Joe and Eckerlein, Christian (2019). Cambodian labour in Chinese-owned enterprises in Sihanoukville. Unpublished internal report. Solidarity Center, Phnom Penh, Cambodia.

Chan, Sok (2020). Preah Sihanouk province to become Special Economic Zone. Khmer Times, 7 February 2020. https://www.khmertimeskh.com/50688097/masterplan-for-preah-sihanouk-province (last accessed 4 March 2020).

Chheang, Vannarith (2017). The political economy of Chinese investment in Cambodia, Trends in Southeast Asia No. 16. Singapore: ISEAS.

Council for Development of Cambodia (2017). Investment Trend. Available at: http://www.cambodiainvest-ment.gov.kh/why-invest-in-cambodia/investment-enviroment/investment-trend.html (last accessed 19 June 2019).

Dara, Voun (2019a). Sihanoukville grapples with illegal buildings. The Phnom Penh Post, 4 January 2019. https://www.phnompenhpost.com/national/sihanoukville-grapples-illegalbuildings (last accessed 3 August 2019).

Davis, Emerson (2018). Chinese investment signals support for Cambodia. FDI intelligence, 29 January 2018. https://www.fdiintelligence.com/News/China-lends-Cambodia-FDI-support (last accessed 19 June 2019).

Ellis-Petersen, Hannan (2018). No Cambodia left: how Chinese money is changing Sihanoukville. The Guardian, 31 July 2018. https://www.theguardian.com/cities/2018/jul/31/nocambodia-left-chinese-money-changing-sihanoukville (last accessed 11 June 2019).

European Commission (2020). Commission decides to partially withdraw Cambodia's preferential access to the EU market. Available at: https://trade.ec.europa.eu/doclib/press/index.cfm?id=2113 (last accessed 2 September 2020). 
Faulder, Dominic and Kawase, Kenji (2018). Cambodians wary as Chinese investment transforms their country. Nikkei Asian Review, 18 July 2018. https://asia.nikkei.com/Spotlight/Cover-Story/Cambodians-wary-as-Chinese-investment-transforms-their-country (last accessed 11 June 2019).

Fifield, Anna (2018). This Cambodian city is turning into a Chinese enclave, and not everyone is happy. Washington Post, 29 March 2018. https://www.washingtonpost.com/world/asia pacific/this-cambodian-city-is-turning-into-a-chinese-enclaveand-not-everyone-is-happy/2018/03/28/6c8963b0-2d8e-11e8-911f-ca7f68bff0fc story.html (last accessed 11 June 2019).

Franceschini, Ivan (2018). Calling the Tunes in Cambodia. In: Golley, Jane, Jaivin, Linda, Farrelly, Paul J., and Strange, Sharon (eds). China Story Yearbook 2018: Power. Canberra: ANU Press, 85-89.

Haffner, Andrew (2020). Restoring Sihanoukville. Southeast Asia Globe, 22 January 2020. https://southeastasiaglobe.com/how-to-restore-sihanoukville/ (last accessed 4 March 2020).

Human Rights Watch (2011). "You'll Be Fired if You Refuse": Labor Abuses in Zambia's Chinese State-owned Copper Mines. Available at: https://www.hrw.org/sites/default/files/reports/zambia1111ForWebUpload.pdf (last accessed 2 September 2020).

Hutt, David (2019). Did Cambodia Just Make a U-Turn on Gambling? The Diplomat, 19 September 2019. https://thediplomat.com/2019/09/did-cambodia-just-make-a-u-turn-ongambling/ (last accessed 4 March 2020).

ILO (2017). China Decent Work Country Programme 2016-2020, Geneva: ILO.

ILO (2018). China partners with the ILO to advance South-South cooperation. ILO, 6 November 2018. Available at: https://www.ilo.org/beijing/information-resources/public-information/press-releases/WCMS 649078/lang--en/index.htm (last accessed 9 May 2020).

ILO (2019). ILO and All China Federation of Trade Unions join forces to implement decent work in Asia Pacific. ILO, 15 June 2019. Available at: https://www.ilo.org/actrav/media-center/pr/WCMS 710621/lang--en/index.htm (last accessed 9 May 2020).

Keeton-Olsen, Danielle and Yuan, Sheila (2019). In Cambodia, Chinese workers earn more, but pay the price with diminished labour rights. Equal Times, 25 February 2019. https://www.equaltimes.org/in-cambodia-chinese-workers-earn?lang=en\#.XUU7jugzY2x (last accessed 3 August 2019).

Khmer Times (2019). Chinese-invested Sihanoukville SEZ is model for SEZ development. Khmer Times, 1 June 2019. https://www.khmertimeskh.com/50609909/chinese-invested-sihanoukville-sez-is-model-for-sez-development-in-cambodia-cambodian-deputy-pm (last accessed 14 March 2020).

Kimsay, Hor (2018). Investment in Cambodia nearly doubles in 2017. The Phnom Penh Post, 7 March 2018. https://www.phnompenhpost.com/business/investment-cambodia-nearlydoubles-2017 (last accessed 13 August 2019). 
Kotoski, Kali and Sokhorng, Cheng (2017). Big trouble in little China? Exploring Chinese investment in Sihanoukville. The Phnom Penh Post, 8 December 2017. https://www.phnompenhpost.com/post-depth-business/big-trouble-little-china-0 (last accessed 11 June 2019).

Kubny, Julia and Voss, Hinrich (2010). The Impact of Chinese Outward Investment: Evidence from Cambodia and Vietnam. Bonn: Deutsches Institut für Entwicklungspolitik. Available at: $\quad$ https://www.eu-china.net/upload/pdf/materialien/11-03-02 Impact\%20of\%20chinese\%20outward\%20investment.pdf (last accessed 2 September 2020)

Kunmakara, May (2019). Sihanoukville welcomes new Chinese development. Khmer Times, 2 August 2019. https://www.khmertimeskh.com/50629514/sihanoukville-welcomes-new-chinese-development/ (last accessed 5 August 2019).

Lee, Ching Kwan (2017). The Specter of Global China: Politics, Labor, and Foreign Investment in Africa. Chicago and London: University of Chicago Press.

Millar, Paul (2018). Seeing red. Southeast Asia Globe, 13 November 2018. https://southeastasiaglobe.com/anti-chinese-sentiment-in-cambodia/ (last accessed 17 June 2019).

Muyhong, Chan and Keeton-Olsen, Danielle (2019). China's unsafe work practices replicated on Cambodia's construction sites. China Labour Bulletin, 22 July 2019. https://clb.org.hk/content/china\%E2\%80\%99s-unsafe-work-practices-replicated-cambodia\%E2\%80\%99s-construction-sites (last accessed 3 August 2019).

Narin, Sun (2019). After Cambodia's Building Collapse, More Construction Sites Found "Without License". VOA Cambodia, 29 June 2019. https://www.voacambodia.com/a/after-cambodia-s-building-collapse-more-construction-sites-found-without-license/4978044.html (last accessed 3 August 2019).

Ng, Desmond and Phang, Charles (2018). China brings casino boom to Cambodian town - but doom to local businesses? Channel News Asia, 20 October 2018. https://www.channelnewsasia.com/news/cnainsider/china-belt-road-casino-boom-sihanoukville-cambodiaphnom-penh-10846730 (last accessed 11 June 2019).

Oya, Carlos and Wanda, Fernandes (2019). Angola Research Brief: Working conditions in Angola. Infrastructure construction and building materials factories. https://www.soas.ac.uk/idcea/publications/reports/file141347.pdf (last accessed 8 July 2019). ICDEA Research Report, SOAS, University of London.

Po, Sovinda and Heng, Kimkong (2019). Assessing the Impacts of Chinese Investments in Cambodia: The Case of Preah Sihanoukville Province. Pacific Forum Issues \& Insights, Vol. 19, Working Paper 4. Honolulu: Pacific Forum. Available at: https://www.pacforum.org/sites/default/files/issuesinsights Vol19WP4 FINAL.pdf (last accessed 20 January 2020).

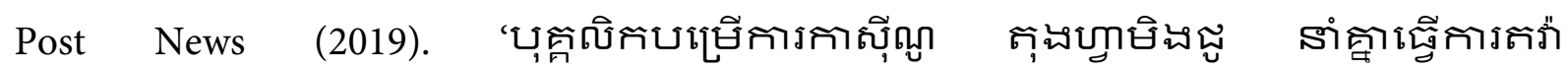

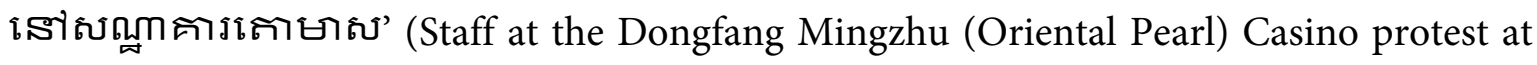
the Gold Lion Hotel). Post News, 8 May 2019. https://postnews.com.kh/local/438528 (last accessed 13 June 2019). 
Prasso, Sheridan (2018). Chinese Influx Stirs Resentment in Once-Sleepy Cambodian Resort. Bloomberg, 21 June 2018. https://www.bloomberg.com/news/features/2018-06-20/chinesecasinos-stir-resentment-on-cambodia-s-coast-of-dystopia (last accessed 11 June 2019).

Reaksmey, Hul (2018). Activists Claim Chinese Investment Fueling Land Disputes in Cambodia. VOA Khmer, 31 October 2018. https://www.voacambodia.com/a/activists-claim-chinese-investment-fueling-land-disputes-in-cambodia/4637185.html (last accessed 30 August 2019).

Schaefer, Florian and Oya, Carlos (2019). Employment patterns and conditions in construction and manufacturing in Ethiopia: A comparative analysis of the road building and light manufacturing sectors. ICDEA Research Report, SOAS, University of London. Available at: https://www.soas.ac.uk/idcea/publications/reports/file141205.pdf (last accessed 8 July 2019).

Sen, David (2019). Casino workers in Sihanoukville demand better working conditions. Khmer Times, 15 July 2019. https://www.khmertimeskh.com/50623930/casino-workers-in-sihanoukville-demand-better-working-conditions (last accessed 15 July 2019).

Senghor, Senh and Sophal, Chan (2019). Inclusive Development and Chinese Direct Investments in Cambodia. Research Report. http://www.cps.org.kh/wp-content/uploads/inclusive-development-and-chinese-direct-investments-in-cambodia.pdf (last accessed 30 July 2019). Centre for Policy Studies, Phnom Penh, Cambodia.

Southern, Nathan Paul (2017). A future without home? Southeast Asia Globe, 6 November 2017. https://southeastasiaglobe.com/construction-cambodia/ (last accessed 3 August 2019).

Spiess, Robin (2019). Show me the money. Southeast Asia Globe, 4 June 2019. https://southeastasiaglobe.com/show-me-the-money/ (last accessed 12 June 2019).

Sovuthy, Khy (2019). Massive payout for Sihanoukville collapse victims. Khmer Times, 2 July 2019. https://www.khmertimeskh.com/50619964/massive-payout-for-sihanoukville-collapse-victims/ (last accessed 3 August 2019).

Thame, Charlie (2017). SEZs and Value Extraction from the Mekong: A case study on the control and exploitation of land and labour in Cambodia and Myanmar's Special Economic Zones. Bangkok: Focus on the Global South.

Turton, Shaun (2020). In Cambodia's Boomtown, a Gamble on Chinese Money Goes Sour. Nikkei Asian Review, 10 January 2020. https://asia.nikkei.com/Business/Industry-in-focus/In-Cambodia-s-boomtown-a-gamble-on-Chinese-money-goes-sour (last accessed 4 March 2020).

Vida, Taing (2019). Ban on living inside buildings under construction. Khmer Times, 5 July 2019. https://www.khmertimeskh.com/50621471/no-one-is-allowed-to-live-inside-a-building-under-construction-said-minister/ (last accessed 3 August 2019).

Vireak, Sim (2019). Sihanoukville: A Cambodian City Losing Its Cambodian-ness. The Diplomat, 20 April 2019. https://thediplomat.com/2019/04/sihanoukville-a-cambodian-city-losing-its-cambodian-ness/ (last accessed 11 June 2019). 
World Bank (2019). Cambodia Economic Update: Recent Economic Developments and Outlook. Selected issue - Investing in Cambodia's Future: Early Childhood Health and Nutrition. Washington, DC: World Bank Group. Available at: http://documents1.worldbank.org/curated/en/843251556908260855/pdf/Cambodia-Economic-Update-Recent-Economic-Developments-and-Outlook.pdf (last accessed 2 September 2020). 